\title{
PENGARUH KUALITAS SISTEM, KUALITAS INFORMASI DAN KUALITAS LAYANAN TERHADAP KEPUASAN PENGGUNA SISTEM INFORMASI MANAJEMEN RUMAH SAKIT DAERAH KALISAT KABUPATEN JEMBER
}

\author{
${ }^{1}$ Dony Setiawan Hendyca Putra, ${ }^{2}$ Meilana Siswanto \\ ${ }^{1}$ Program Studi Rekam Medik Jurusan Kesehatan , ${ }^{2}$ Program Studi Teknik Enenergi Terbarukan Jurusan \\ Teknik, Politeknik Negeri Jember \\ Jalan Mastrip Kotak Pos 164 Jember \\ donssend@gmail.com
}

\begin{abstract}
Technology and information systems have developed very rapidly. The information system at this time to be very needed by an organization, company or individual to have the ease, speed, and accuracy in processing and obtaining data or information. Hospital Kalisat in has experienced many problems associated with the data and information of patients, employees, schedules, medical records, queues, medicine, nursing, finance, the amount and effectiveness of employees as well as the room, and so forth. These problems include the process of entering data and search, especially if the system is not using the computer that will be difficult and requires a long time. This research is a quantitative, where there are three independent variables and one dependent variable. Researchers conducted a multiple regression analysis to investigate the influence of the independent variables on the dependent variable. The results obtained are quality systems have a positive influence and significant impact on user satisfaction in hospital management information system Kalisat. This is evidenced by the T-count> T-table (-1.627> -1.187) which means that H0 is rejected. The quality of information has a positive and significant impact on user satisfaction in hospital management information system Kalisat. This is evidenced by the T-count> T-table (-2.341> -1.187) which means that H0 is rejected. Quality of service has a positive influence and significant impact on user satisfaction in hospital management information system Kalisat. System quality, information quality and service quality to the quality of the information system users have a positive influence and significant impact on user satisfaction in hospital management information system Kalisat. This is evidenced by the T-count> T table (4.319> 3.297) which means that $\mathrm{HO}$ refused. Based on the above results the researchers to conclude that the system quality, information quality and service quality has a significant influence on user satisfaction SIMRS. Suggestions for SIMRS Kalisat researcher must maintain quality in order to maintain user satisfaction SIMRS Kalisat Key words: system quality, information quality, service quality, user satisfaction
\end{abstract}

\begin{abstract}
Abstrak
Teknologi dan sistem informasi telah mengalami perkembangan yang sangat pesat. Sistem informasi pada saat ini menjadi sangat dibutuhkan oleh suatu organisasi, perusahaan, maupun perorangan untuk mendapat kemudahan, kecepatan, dan ketepatan dalam mengolah dan memperoleh data dan atau informasi. Rumah Sakit Kalisat di memiliki banyak masalah yang dialami terkait dengan data-data serta informasi pasien, pegawai, jadwal, rekam medis, antrian, obat-obatan, perawatan, keuangan, jumlah dan efektifitas pegawai serta ruangan, dan lain sebagainya. Masalah tersebut meliputi dalam proses memasukkan data dan pencarian, terlebih lagi bila sistem belum menggunakan komputer hal tersebut akan sulit dan membutuhkan waktu yang tidak sebentar. Jenis penelitian ini adalah kuantitatif, dimana terdapat 3 variabel bebas dan 1 variabel terikat. Peneliti melakukan uji regresi linier berganda untuk mengetahui adanya pengaruh dari variabel bebas terhadap variabel terikat. Hasil yang didapatkan adalah kualitas sistem memiliki pengaruh yang positif dan signifikan terhadap kepuasan pengguna pada sistem informasi manajemen rumah sakit kalisat. Hal ini dibuktikan dengan T-hitung >T-tabel $(-1,627>-1,187)$ yang berarti H0 ditolak. Kualitas informasi memiliki pengaruh yang positif dan signifikan terhadap kepuasan pengguna pada sistem informasi manajemen rumah sakit kalisat. Hal ini dibuktikan dengan T-hitung $>$ T-tabel $(-2,341>-1,187)$ yang berarti H0 ditolak. Kualitas pelayanan memiliki pengaruh yang positif dan signifikan terhadap kepuasan pengguna pada sistem informasi manajemen rumah sakit kalisat. Hal ini dibuktikan dengan T-hitung >T-tabel (4,319 > 3 ,297) yang berarti H0 ditolak. Berdasarkan hasil diatas peneliti dapat menyimpulkan bahwa kualitas sistem, kualitas informasi dan kualitas layanan memberikan pengaruh yang signifikan terhadap kepuasan pengguna SIMRS. Saran peneliti untuk SIMRS Kalisat harus di pertahankan kualitasnya supaya dapat mempertahankan kepuasan pengguna SIMRS Kalisat.
\end{abstract}

Kata kunci: kualitas sistem, kualitas informasi, kualitas layanan, kepuasan pengguna 


\section{PENDAHULUAN}

Peraturan Menteri Kesehatan Republik Indonesia nomor 1171/ MENKES/ PER/ VI/ 2011 yang menyebutkan bahwa "setiap rumah sakit wajib melaksanakan Sistem Informasi Rumah Sakit", maka rumah sakit yang ada di Indonesia mulai menerapkan sistem untuk meningkatkan pelayanan. SIMRS adalah suatu sistem terkomputerisasi yang mampu melakukan pengolahan data secara cepat, akurat, dan menghasilkan sekumpulan informasi yang saling berinteraksi untuk diberikan kepada semua tingkatan manajemen di rumah sakit. Hasil informasi dari data yang telah diolah yaitu berupa laporan, dapat digunakan oleh pengguna dalam mengambil keputusan untuk peningkatan upaya pelayanan kesehatan.

Teknologi dan sistem informasi telah mengalami perkembangan yang sangat pesat. Sistem informasi pada saat ini menjadi sangat dibutuhkan oleh suatu organisasi, perusahaan, maupun perorangan untuk mendapat kemudahan, kecepatan, dan ketepatan dalam mengolah dan memperoleh data dan atau informasi. Dengan mempertimbangkan berbagai solusi yang ditawarkan oleh sistem informasi, penerapan sistem informasipun tidak hanya terbatas pada bidang komputer dan teknologi informasi, tetapi juga telah diterapkan dalam berbagai aspek kehidupan, tidak terkecuali pada dunia kesehatan.

Rumah Sakit Kalisat di memiliki banyak masalah yang dialami terkait dengan data-data serta informasi pasien, pegawai, jadwal, rekam medis, antrian, obat-obatan, perawatan, keuangan, jumlah dan efektifitas pegawai serta ruangan, dan lain sebagainya. Masalah tersebut meliputi dalam proses memasukkan data dan pencarian, terlebih lagi bila sistem belum menggunakan komputer hal tersebut akan sulit dan membutuhkan waktu yang tidak sebentar.

Berdasarkan studi pendahuluan yang peneliti lakukan di RS Kalisat di Jember ditemukan beberapa permasalahan diantaranya: Pencarian informasi data pasien, pegawai RS, memerlukan waktu lama dan sulit karena belum menggunakan sistem informasi manajemen RS. Demikian juga pencarian informasi tentang perawatan pada bangsal, informasi jadwal pasien dan dokter pada RS yang belum menggunakan sistem informasi menjadi sulit dan lebih lama. Analisa tentang efektifitas pegawai dan ruangan pada RS, laporan keuangan RS juga menjadi tidak efisien dan memakan banyak waktu tanpa penggunaan sistem informasi RS.

Sampai saat ini, penelitian mengenai kesuksesan dari penerapan sistem informasi manajemen RS dan pengaruh kualitas sistem tersebut terhadap kepuasan pengguna di rumah sakit Kalisat Jember belum pernah dilakukan. Pengaruh kualitas pelayanan sistem informasi RS terhadap kepuasan pengguna, pengaruh kualitas informasi terhadap pemakaian pada sistem informasi manajemen RS, dan pengaruh kualitas sistem terhadap pemakaian pada sistem informasi manajemen RS di rumash sakit Kalisat juga belum pernah diteliti sebelumnya. Demikian juga penelitian mengenai pengaruh kualitas layanan terhadap pemakaian pada sistem informasi manajemen RS belum pernah dilakukan di RS Kalisat. Sehingga perlu dilakukan penelitian mengenai sistem informasi manajemen rumah sakit untuk dapat mengetahui dengan pasti sukses tidaknya penerapan sistem informasi tersebut di RS Kalisat. Penelitian terhadap sistem informasi manajemen rumah sakit diharapkan dapat menjadi bahan pertimbangan dalam mengembangkan sistem informasi manajemen rumah sakit.

Penelitian ini akan menganalisis pengaruh kualitas sistem, kualitas informasi dan kualitas pelayanan terhadap kepuasan pengguna pada sistem informasi manajemen Rumah Sakit Daerah Kalisat Jember tahun 2016. Berdasarkan uraian latar belakang diatas peneliti tertarik untuk melakukan penelitian dengan judul "Pengaruh Kualitas Sistem, Kualitas Informasi dan Kualitas Pelayanan Terhadap Kepuasan Pengguna pada Sistem Informasi Manajemen Rumah Sakit Daerah Kalisat Jember tahun 2016".

\section{TINJAUAN PUSTAKA}

Sistem informasi manajemen merupakan sistem buatan manusia yang berisi tentang manusia, kekuasaan, organisasi, kebijaksanaan, dan prosedur yang bertujuan untuk merencanakan dan mengontrol pekerjaan dalam organisasi. Tiga kegiatan utama sistem manajemen adalah perencanaan, pengontrolan, dan pembuatan keputusan (Sidartha, 1997).

Model kesuksesan sistem informasi yang dikembangkan merupakan model yang paling banyak digunakan sebagai ukuran kesuksesan sistem informasi. Kualitas sistem biasanya berfokus pada karakteristik kinerja sistem. Kualitas sistem merupakan ciri karakteristik kualitas yang diinginkan dari sistem informasi itu sendiri dan kualitas informasi yang diinginkan informasi karakteristik produk.Kualitas sistem dalam sistem informasi dalam sistem informasi klinik ini menyangkut keterkaitan fitur dalam sistem termasuk performa sistem dan user interface (DeLone dan McLean, 2003).

DeLone dan McLean (2003) menyatakan bahwa kualitas informasi mengukur kualitas output dari sistem informasi, yaitu kualitas yang dihasilkan 
Dony Setiawan Hendyca P, Meilana Siswanto, Pengaruh Kualitas Sistem Informasi dan Kualitas Layanan Terhadap Kepuasan Pengguna Sistem Informasi Manajemen Rumah Sakit Daerah Kalisat

oleh sistem informasi, terutama dalam bentuk laporan-laporan (reports). Kualitas layanan merupakan kulitas dukungan yang didapatkan oleh pengguna dari departemen sistem informasi (dalam hal ini merupakan pengembang sistem informasi rumah sakit. Kepuasan pengguna sistem informasi merupakan respon dan umpan balik yang dimunculkan pengguna setelah memakai sistem informasi.

\section{TUJUAN DAN MANFAAT} Tujuan

1) Mengetahui kualitas sistem pada sistem informasi manajemen rumah sakit, dan pengaruhnya terhadap kepuasan pengguna sistem informasi manajemen Rumah Sakit Daerah Kalisat Jember tahun 2016 ; 2) Mengetahui kualitas informasi pada sistem informasi manajemen rumah sakit, dan pengaruhnya terhadap kepuasan pengguna sistem informasi manajemen Rumah Sakit Rumah Sakit Daerah Kalisat Jember tahun 2016; 3) Mengetahui kualitas pelayanan pada sistem informasi manajemen rumah sakit, dan pengaruhnya terhadap kepuasan pengguna sistem informasi manajemen Rumah Sakit Daerah Kalisat Jember tahun 2016; 4) Menganalisis pengaruh kualitas sistem, kualitas informasi dan kualitas pelayanan terhadap kepuasan pengguna sistem informasi manajemen Rumah Sakit Daerah Kalisat Jember Jember tahun 2016.

Manfaat

1)Pengguna akan mendapatkan keuntungan dengan adanya update sistem dari pengembang terkait dengan kelayakan sistem; 2) Dengan mengetahui kelayakan sistem, maka pengembang dapat mengembangkan update sistem maupun sistem lain yang lebih baik.

\section{METODE PENELITIAN}

Penelitian ini termasuk dalam penelitian kuantitatif, karena data yang digunakan dinyatakan dalam angka dan di analisis dengan teknik statistik. Peneliti melakukan penelitian di Rumah Sakit Kalisat Kabupaten Jember tahun 2016.

Dalam penelitian ini populasi yang digunakan adalah semua orang yang telah menggunakan sistem informasi manajemen rumah sakit dimana sistem informasi ini telah diterapkan, yaitu di Rumah Sakit Kalisat Kabupaten Jember.

Teknik pengumpulan data dalam penelitian ini adalah dengan menggunakan kuesioner (angket). Dalam penelitian ini variabel penelitian dibedakan menjadi variabel bebas dan variabel terikat. Dimana yang menjadi variabel bebas adalah : kualitas sistem yang dilambangkan dengan X1, kualitas informasi yang dilambangkan dengan X2, kualitas layanan yang dilambangkan dengan X3, sedangkan yang menjadi variabel terikat adalah kepuasan pengguna yang dilambangkan dengan Y. Dalam hal ini peneliti melakukan uji regresi linier berganda.

\section{HASIL DAN LUARAN YANG DICAPAI}

Tabel 5.1 Kualitas sistem terhadap

kepuasan pengguna tahun 2016

\begin{tabular}{|l|c|c|c|}
\hline \multicolumn{1}{|l|}{ Pernyataan } & hitung & tabel & \multicolumn{1}{c|}{ ke } \\
ualitas $\mathrm{K}$ & & & \\
$\begin{array}{l}\text { Sistem } \\
\text { terhadap } \\
\text { Kepuasan } \\
\text { Pengguna }\end{array}$ & 1,627 & 1,187 & Berpengaruh \\
\hline
\end{tabular}

Hasil penelitian ini menunjukkan bahwa kualitas sistem memiliki pengaruh terhadap kepuasan pengguna. Hal ini dibuktikan dengan lebih besarnya T-hitung dibandingkan dengan pada tabel $(-1,627>-1,187)$. Pengukur-pengukur pada kualitas sistem seperti, kemudahan penggunaan, kemudahan dipelajari, kecepatan akses, keandalan sistem, fleksibilitas, kegunaan fitur dan fungsi, serta keamanan pada sistem informasi klinik memberikan pengaruh pada kepuasan pengguna.

Tabel 5.2 Kualitas informasi terhadap kepuasan pengguna tahun 2016

\begin{tabular}{|c|c|c|c|}
\hline Pernyataan & hitung & tabel & keterangan \\
\hline $\begin{array}{c}\text { Kualitas } \\
\text { Informasi terhadap }\end{array}$ & 2,34 & 1,18 & Berpengaruh \\
KepuasanPengguna & 1 & 7 & \\
\hline
\end{tabular}

Hasil penelitian ini menunjukkan bahwa kualitas informasi memiliki pengaruh terhadap kepuasan pengguna. Hal ini dibuktikan dengan lebih besarnya T-hitung dibandingkan dengan pada tabel $(-2,341>-1,187)$. Pengukur-pengukur pada kualitas informasi seperti, akurasi informasi, kelengkapan informasi yang disajikan, bentuk output dari informasi yang disajikan, ketepatan waktu, dan relevansi informasi yang disajikan pada sistem informasi klinik memberikan pengaruh pada kepuasan pengguna.

Tabel 5.3 Kualitas pelayanan terhadap kepuasan pengguna tahun 2016

\begin{tabular}{|l|l|l|l|}
\hline \multicolumn{1}{|c|}{ Pernyataan } & hitung & tabel & keterangan \\
\hline $\begin{array}{l}\text { Kualitas } \\
\text { Pelayanan } \\
\text { terhadap } \\
\text { Kepuasan } \\
\text { Pengguna }\end{array}$ & 3,459 & 1,187 & Berpengaruh \\
\hline
\end{tabular}

Hasil penelitian ini menunjukkan bahwa kualitas layanan memiliki pengaruh terhadap kepuasan pengguna. Hal ini dibuktikan dengan 
lebih besarnya T-hitung dibandingkan dengan pada tabel $(3,459>1,187)$. Pengukur-pengukur pada kualitas layanan seperti, kecepatan respon, kemampuan teknikdan empati memberikan pengaruh pada kepuasan pengguna SIMRS Kalisat.

Berdasarkan hal tersebut maka dapat disimpulkan bahwa kualitas layanan memiliki pengaruh signifikan terhadap kepuasan pengguna pada sistem informasi rumah sakit daerah kalisat.

Tabel 5.4 Pengaruh kualitas sistem, kualitas informasi, dan kualitas layanan terhadap kepuasan pengguna SIMRS Kalisat Jember 2016

\begin{tabular}{|l|l|l|l|}
\hline \multicolumn{1}{|c|}{ Pernyataan } & F $_{\text {hitung }}$ & $\mathrm{F}_{\text {tabel }}$ & keterangan \\
\hline $\begin{array}{l}\text { Kualitas } \\
\text { Sistem, }\end{array}$ & & & \\
$\begin{array}{l}\text { Informasi, dan } \\
\text { Pelayanan } \\
\text { terhadap }\end{array}$ & 4,319 & 3,197 & Berpengaruh \\
$\begin{array}{l}\text { Kepuasan } \\
\text { Pengguna }\end{array}$ & & & \\
\hline
\end{tabular}

Berdasarkan tabel diatas maka dapat disimpulkan bahwa variabel kualitas sistem, variabel kualitas informasi, dan variabel kualitas pelayanan berpengaruh secara bersama-sama terhadap kualitas pengguna dikarenakan nilai dari t hitung lebih besar dari t tabel yaitu 4,319 > 3,197.

\section{KESIMPULAN DAN SARAN}

1. Kualitas sistem memiliki pengaruh yang positif dan signifikan terhadap kepuasan pengguna pada sistem informasi manajemen rumah sakit kalisat. Hal ini dibuktikan dengan T-hitung >T-tabel $(-1,627>-1,187)$ yang berarti $\mathrm{HO}$ ditolak.

2. Kualitas informasi memiliki pengaruh yang positif dan signifikan terhadap kepuasan pengguna pada sistem informasi manajemen rumah sakit kalisat. Hal ini dibuktikan dengan T-hitung > T-tabel $(-2,341>-1,187)$ yang berarti $\mathrm{HO}$ ditolak.

3. Kualitas pelayanan memiliki pengaruh yang positif dan signifikan terhadap kepuasan pengguna pada sistem informasi manajemen rumah sakit kalisat. Hal ini dibuktikan dengan T-hitung > T-tabel $(3,459>1,187)$ yang berarti $\mathrm{HO}$ ditolak.

4. Kualitas sistem, kualitas informasi dan kualitas pelayanan terhadap kualitas pengguna sistem informasi memiliki pengaruh yang positif dan signifikan terhadap kepuasan pengguna pada sistem informasi manajemen

rumah sakit kalisat. Hal ini dibuktikan dengan T-hitung > T-tabel $(4,319>3,297)$ yang berarti H0 ditolak.
Tim penelitian dengan judul Pengaruh kualitas sistem, kualitas informasi, kualitas layanan terhadap kepuasan pengguna SIMRS Kalisat Jember" mengucapkan banyak terima kasih kepada Politeknik Negeri Jember atas dukungan pendanaan sehingga kegiatan ini dapat terlaksana dengan baik.

\section{DAFTAR PUSTAKA}

Adri Kristanto. 2004. Perancangan Sistem Informasi dan Aplikasinya. Yogyakarta: Gava Media.

Apit Riana. 2006. Evaluasi kinerja sistem informasi manajemen ditinjau dari aspek persepsi pengguna dalam mendukung proses manajemen di rumah sakit PKU Muhammadiyah Yogyakarta. SemarangArikunto, Suharsimi. 2010. Prosedur Penelitian Suatu Pendekatan Praktik.Jakarta: Rineka Cipta.

Depkes RI. 2003. Sistem Informasi Rumah Sakit di Indonesia (Sistem Pelaporan RS Revisi V). Jakarta: Departemen Kesehatan.

Jogiyanto.2007. Model Kesuksesan Sistem Teknologi Informasi. Yogyakarta: Penerbit ANDI.

Masrek Mohamad Noorman, Adnan Jamaludin and Sobariah Awang Mukhtar. 2010. Evaluating Academic Library Portal Evectiveness A Malaysian Case Study. Library Review Vol. 59 No. 3, 2010. 198-212. Emerald Group Publishing Limited

Petter Stacie, W DeLone and E. R. McLean. (2008). Measuring Information Systems Success: Models, Dimensions, Measures, and Interrelationships. European Journal of Information Systems. 236-263.

Rustiyanto. 2010. Statistik Rumah Sakit Untuk Pengambilan Keputusan. Cetakan Pertama. Yogyakarta: Graha Ilmu.

Sabarguna. 2008. Sistem Bantu Keputusan untuk Rawat Jalan dan Rawat Inap Rumah Sakit. Jakarta: CV. Karya Bakti Mandiri.

Smith, Diana Garcia. 2007. Testing A Model To Predict Successful Clipnical Information System. Dissertation. The University of Arizona.

\section{UCAPAN TERIMAKASIH}

